\title{
Is There Any Prognostic Significance of the Level of Change in SUVmax after SBRT in Patients with Early Stage NSCLC?
}

\author{
Gokhan YAPRAK ${ }^{1}$, Alaattin OZEN ${ }^{2}$, Fuzuli TUGRUL ${ }^{3}$, Sule OZUGUR $^{4}$, Naciye ISIK ${ }^{1}$ \\ ${ }^{1}$ University of Health Sciences, Kartal Dr. Lütfi Kırdar Training and Research Hospital, \\ Department of Radiation Oncology, Istanbul \\ ${ }^{2}$ Eskisehir Osmangazi University, Faculty of Medicine, Department of Radiation Oncology, Eskisehir \\ ${ }^{3}$ Eskisehir City Hospital, Radiation Oncology Clinic, Eskisehir \\ ${ }^{4}$ University of Health Sciences, Kartal Dr. Lütfi Kırdar Training and Research Hospital, \\ Department of Nuclear Medicine, Istanbul, TURKEY
}

\begin{abstract}
We aimed to evaluate the prognostic significance of the level of change in SUVmax ( $S$ SUVmax) on pre and post-treatment PET/ CT in early stage non-small cell lung cancer (esNSCLC) patients treated with stereotactic body radiotherapy (SBRT). Between November 2009-February 2018, pathologically proven esNSCLC patients (T1-2NOM0) treated with CyberKnife as primary treatment alone and who had pre and post-treatment PET/CT were retrospectively identified. The $\triangle$ SUVmax was calculated using formula $\Delta$ SUVmax = (PreSBRT SUVmax- PostSBRT SUVmax) / (PreSBRT SUVmax). A total of 48 patients were identified. All patients had biopsy-confirmed NSCLC. Median dose was 45 Gy / 3 fr (range: 45-60 Gy / 3-5 fr). According to EORTC metabolic response criteria at 12-16 weeks after SBRT, 8 (16.7\%) patients achieved complete response, 35 (72.9\%) patients achieved partial response. AUC was calculated as 0.62 for cutoff $\triangle$ SUVmax. Median PFS was 15 (range: 6-54) vs 59 (range: 10-92) months $(p=0.012)$ and median OS was 36 (range: 10-75) vs 70 (range: 23-92) months $(p=0.045)$ in patients with $\Delta S U V \max <0.62$ and $\geq 0.62$, respectively. In both univariate and multivariate analysis, the lower $\Delta$ SUVmax (as both dichotomous and continuous variable) was determined as a negative prognostic factor on PFS and it has been showed that the lower $\triangle$ SUVmax (only as a dichotomous variable) is a negative prognostic factor on OS in multivariate analysis. In conclusion, in esNSCLC patients who were treated with SBRT, a $\Delta$ SUVmax higher than 0.62 demonstrates better PFS and OS.
\end{abstract}

Keywords: Stereotactic body radiotherapy (SBRT), Early stage non-small cell lung cancer, SUVmax, Positron Emission Tomography/ Computed Tomography (PET/CT)

\section{ÖZET}

\section{Erken Evre Akciğer Kanserli Hastalarda SBRT Sonrası SUVmax Değişiminin Prognostik Önemi Varmı?}

Stereotaktik vücut radyoterapisi (SBRT) ile tedavi edilen erken evre küçük hücre dışı akciğer kanseri (esNSCLC) hastalarında tedavi öncesi ve sonrası PET / BT'deki SUVmax'taki değişim seviyesinin prognostik önemini değerlendirmeyi amaçladık. Kasım 2009-Șubat 2018 arasında patolojik olarak ispatlanmış esNSCLC (T1-2NOMO) nedeniyle CyberKnife ile tedavi edilen, tedavi öncesi ve sonrasında PET / CT'si olan hastalar geriye dönük olarak değerlendirildi. $\triangle$ SUVmax, $\triangle$ SUVmax= (PreSBRT SUVmax - PostSBRT SUVmax) / (PreSBRT SUVmax) formülü kullanılarak hesaplandı. Toplam 48 hasta dahil edildi.Tüm hastalarda biyopsi ile onaylanmış KHDAK tanıSı mevcuttu. Ortanca doz 45 Gy / 3 fr (range: 45-60 Gy / 3-5 fr) idi. SBRT'den 12-16 hafta sonra EORTC metabolik cevap kriterlerine göre, 8 (\%16.7) hastada tam yanıt, 35 (\% 72.9) hastada kısmi yanıt elde edildi. AUC ile $\triangle S U V m a x$ cutoff değeri 0.62 olarak hesaplandı. 
International Journal of Hematology and Oncology

$\triangle$ SUVmax < 0.62 ve $\triangle$ SUVmax $\geq 0.62$ olan hastalarda sırasılyla ortanca PFS 15 ay'a (range: 6-54), 59 ay (range: 10-92) ( $p=0.012)$ iken,ortanca OS 36 ay'a (range: 10-75),70 ay (range: 23-92) ( $p=0.045)$ idi. Hem tek değişkenli hem de çok değişkenli analizlerde, düşük $\triangle S U V \max$ (hem ikatagorik hem de sürekli değişken olarak) değeri, PFS üzerinde negatif bir prognostik faktör olarak belirlenmişken, çok değişkenli analizde düşük $\triangle S U V \max$ (sadece katagorik değişken olarak) değerinin OS üzerinde negatif prognostik faktör olduğu gösterilmiştir.Sonuç olarak, SBRT ile tedavi edilen esNSCLC hastalarda, 0.62'den yüksek bir $\triangle S$ SUVmax daha iyi PFS ve OS gösterir.

Anahtar Kelimeler: Stereotaktik beden radyoterapisi, Erken evre küçük hücre dışı akciğer kanseri, Suvmax, Pozitron emisyon tomografisi/Bilgisayarlı Tomografi (PET/BT)

\section{INTRODUCTION}

Stereotactic body radiotherapy (SBRT) is a rising innovation that is profoundly effective and precise radiation beams are utilized to convey high dosages in one to five fractions to tumor targets. ${ }^{1}$ Over the past years, SBRT has been utilized progressively in early-stage non-small cell lung carcinoma (esNSCLC) patients. SBRT is a powerful and alternative treatment to surgery for patients with esNSCLC and is accepted as a standard treatment for esNSCLC patients who are not qualified for surgery. ${ }^{2,3} 3$-year survival and local control rate has been reported as $55.8 \%$ and $90.6 \%$ as a result of prospective RTOG 0236 study. ${ }^{3}$ Additionally, it has been shown that the 5-year in overall survival (OS) for SBRT (42\%) was significantly better as than that for 3D conformal radiotherapy (CRT) (20\%) in patients with medically inoperable stage I esNSCLC. ${ }^{4}$ In view of the result of a retrospective and two randomized studies, it has been suggested that SBRT could be a suitable alternative for patients with operable esNSCLC. . $^{5,6}$

It is recognized that positron-emission tomography / computed tomography (PET/CT), which is a metabolic imaging procedure, demonstrates treatment response at an earlier time than conventional anatomic imaging strategies. ${ }^{7}$ Morphological imaging strategies have limitations such as about separation between residual tumor and necrotic or fibrotic scar tissue. ${ }^{8}$ Eschmann et al. has reported the sensitivity, specificity and accuracy of PET/CT in identifying residual tumor as $95 \%, 80 \%$ and $91 \%$, respectively. In addition, a longer survival has been reported in patients with metabolic complete response or reduction over $80 \%$ in SUVmax compared with those who showed partial metabolic response. ${ }^{9}$

${ }^{18}$ F-Fludeoxyglucose (FDG) uptake in PET/CT can give extra information about tumor's biological characteristics and it might be a useful biomarker to identifying high risk esNSCLC patients for disease progression. ${ }^{10}$ The predictive impact of PET/ CT for assessment of response after SBRT in patients with NSCLC has been investigated in trials and it has been observed that metabolic changes in tumor occurring at 12 weeks after SBRT are extremely significant. ${ }^{11}$ Also, PET/CT in various timings after SBRT has been studied and in these trials the correlation between tumor response / prognosis and various parameters which are acquired from pre and post-treatment PET/CT in esNSCLC patients who were treated with SBRT has been investigated. ${ }^{12-17}$ In our study, we aimed to assess the prognostic significance of the level of change in maximum standard uptake value ( $\triangle \mathrm{SUVmax})$ between pre and post SBRT in esNSCLC patients. For this aim, here, we tried to identify a $\triangle$ SUVmax cutoff value to predict more aggressive disease in patients with esNSCLC which is a potentially curable disease with SBRT.

\section{PATIENTS AND METHODS}

\section{Patients}

After excluding patients who do not have PET/ $\mathrm{CT}$ at 3rd month after SBRT, we retrospectively identified 48 of 66 patients with pathologically proven esNSCLC (T1-2N0M0) who were treated with SBRT using CyberKnife as primary treatment alone between November 2009 and February 2018. Patients who did not fulfill have one of these the following criteria were excluded from this study; (1) histologically confirmed NSCLC; (2) T1 or T2/ NO lung cancer on pretreatment staging; (3) SBRT treatment as curative intent; (4) pretreatment PET/ CT scan; (5) posttreatment PET/CT scan. This 
study was started after the approval was obtained of the ethics committee of the authors' institution.

\section{Radiotherapy Technique and Specifications}

All patients in the study were treated with the $\mathrm{Cy}$ berKnife Robotic Radiosurgery System (Accuray, Inc, Sunnyvale, CA). Immobilization was achieved with vacuum couch in supine position. Simulation CT (GE Healthcare, Waukesha, WI, USA) was performed using $1.25-\mathrm{mm}$ thick slices by administering intravenous contrast material. All lesions were treated with median 45 Gy / 3 fr (range: 45-60 Gy / 3-5 fr) every other day. To select the optimal treatment plan, dose-volume histograms were calculated for the target and critical structures. Median reference isodose of the prescription dose to the PTV was $87 \%$ (range: $70 \%-92 \%$ ). Lower PTV coverage with most appropriate plan was accepted if surrounding organs-at-risk were deemed to be at excess risk for toxicity. We calculated the Biologically Equivalent Dose (BED) for tumor in all patients according to the linear-quadratic formulation (tumor $\alpha / \beta=10$ ). Three image guidance systems (the XSight Spine Tracking System, the Synchrony Respiratory Motion Tracking System, and the Fiducial Tracking System) onboard the CyberKnife platform was used. The motion correlation between the external infrared emitters and internal fiducial markers updated periodically during treatment.

\section{Analysis of 18F-Fluorodeoxyglucose PET}

All patients had pretreatment PET/CT in 3 weeks before SBRT and post treatment PET/CT at 12-16 weeks after SBRT. The level of change in SUVmax $(\triangle S U V \max )$ was also calculated from pre and post treatment PET/CT by using formula $\triangle \mathrm{SUVmax}=$ (PostSBRT SUVmax- PreSBRT SUVmax) / (PreSBRT SUVmax $) . \triangle S U V \max =($ PreSBRT SUV max PostSBRT SUVmax ) / (PreSBRT SUVmax)

\section{Statistical Analysis}

Continuous variables were analyzed with KruskalWallis tests or Mann Whitney-U tests. Categorical variables were analyzed with Pearson chi-square or Fisher exact tests. We used a receiver operating characteristic (ROC) curves to determine an

\begin{tabular}{|c|c|c|c|}
\hline & \multicolumn{2}{|c|}{ Level of Change in SUVmax } & \multirow[t]{2}{*}{$\mathbf{p}$} \\
\hline & $<0.62 \mathrm{n}(\%)$ & $\geq 0.62 \mathrm{n}(\%)$ & \\
\hline \multicolumn{4}{|l|}{ Gender } \\
\hline Female & $2(6.5)$ & $2(11.8)$ & \multirow[t]{2}{*}{ NSD } \\
\hline Male & $29(93.5)$ & $15(88.2)$ & \\
\hline \multicolumn{4}{|c|}{ Age at diagnosis (years) } \\
\hline Median & 67 & 67 & \multirow[t]{2}{*}{ NSD } \\
\hline Range & $54-84$ & $56-82$ & \\
\hline \multicolumn{4}{|l|}{ KPS } \\
\hline Median & 90 & 80 & \multirow{4}{*}{ NSD } \\
\hline Range & $60-100$ & $60-90$ & \\
\hline$<80$ & 4 (12.9) & $6(35.3)$ & \\
\hline$\geq 80$ & $27(87.1)$ & $11(64.7)$ & \\
\hline \multicolumn{4}{|l|}{ Tumor Size (mm) } \\
\hline Median & 27 & 20 & \multirow[t]{2}{*}{ NSD } \\
\hline Range & $15-43$ & $11-45$ & \\
\hline \multicolumn{4}{|l|}{ T stage } \\
\hline $\mathrm{T} 1$ & $21(67.7)$ & $13(76.5)$ & \multirow[t]{2}{*}{ NSD } \\
\hline $\mathrm{T} 2$ & $10(32.3)$ & $4(23.5)$ & \\
\hline \multicolumn{4}{|l|}{ NSCLC histology } \\
\hline Squamous & $13(41.9)$ & 9 (52.9) & \multirow[t]{3}{*}{ NSD } \\
\hline Adenocarcinoma & $8(25.8)$ & $5(29.4)$ & \\
\hline Other/unidentified & $10(32.3)$ & $3(17.6)$ & \\
\hline $\begin{array}{l}\text { KPS = Karnofsky } P \\
\text { cell lung cancer, NS }\end{array}$ & $\begin{array}{l}\text { Performance Scc } \\
\text { SD= No Significa }\end{array}$ & $\begin{array}{l}\text { re, NSCLC }=\mathrm{NC} \\
\text { tt Difference }\end{array}$ & \\
\hline
\end{tabular}

appropriate cut-off value for the $\triangle \mathrm{SUVmax}$ to predict OS and PFS, which was above and below cutoff value. Patients were divided into two groups according with this result. Kaplan Meier method was applied to estimate the survival data and it was compared by use of the Mantel-Cox log-rank test. It has been determined by Cox proportional hazards regression whether $\triangle \mathrm{SUVmax}$, age, KPS, gender, T stage, PTV volume, tumor histology, BED10 influenced outcomes. Progression free survival (PFS) was defined as the time from biopsy to any of first event such as local, regional and/or distant relapse or death from any cause. The overall survival (OS) was defined as the time from dates of diagnosis biopsy until death from any cause. SPSS 


\begin{tabular}{|c|c|c|c|}
\hline & \multicolumn{2}{|c|}{ Level of Change in SUVmax } & \multirow[t]{2}{*}{$\mathbf{p}$} \\
\hline & $<0.62$ n (\%) & $\geq 0.62$ n (\%) & \\
\hline \multicolumn{4}{|l|}{ PTV volume (cc) } \\
\hline Median & 41.86 & 36.01 & NSD \\
\hline Range & $11.95-85.14$ & $14.59-91.35$ & \\
\hline \multicolumn{4}{|c|}{ Reference Isodose line } \\
\hline Median & 87 & 86 & NSD \\
\hline Range & $70-92$ & $70-91$ & \\
\hline \multicolumn{4}{|c|}{ SBRT dose (Gy) / fr } \\
\hline Median & $45 / 3$ & $45 / 3$ & \\
\hline Range & $45-60 / 3-5$ & $45-60 / 3-5$ & NSD \\
\hline \multicolumn{4}{|l|}{ BED10 (Gy) } \\
\hline Median & 112.5 & 112.5 & NSD \\
\hline Range & $100-180$ & $100-151$ & \\
\hline \multicolumn{4}{|c|}{ Tumor-tracking system } \\
\hline X-Sight Lung & $25(80.6)$ & $14(82.4)$ & NSD \\
\hline X-Sight Spine & $3(9.7)$ & $1(5.9)$ & \\
\hline Gold Fiducial & $3(9.7)$ & $2(11.8)$ & \\
\hline
\end{tabular}

software (version 21.0; SPSS Inc., Armonk, NY, USA) was used to perform all statistical analyses. $\mathrm{p}$ values $<0.05$ were considered statistically significant.

\section{RESULTS}

\section{Patient characteristics}

Analysiszed of all patients in the present study and their clinicopathological and treatment characteristics are presented in Table 1 and 2. A total of 48 patients with median age of 67 (range: 54-84) years old were identified between November 2009 and February 2018. All patients had biopsy-confirmed NSCLC, with 22 (45.8\%) having squamous cell carcinoma and $13(27.1 \%)$ having adenocarcinoma. The median tumor size was $26 \mathrm{~mm}$ (range: 1145). According to the AJCC 7th edition, tumor Tstage distribution was as follows; T1: 34 (70.8\%), T2: $14(29.2 \%)$.

\begin{tabular}{|c|c|c|c|}
\hline \multicolumn{4}{|c|}{ Table 3. Patients' progress } \\
\hline & \multicolumn{2}{|c|}{ Level of Change in SUVmax } & \multirow[t]{2}{*}{$\mathbf{p}$} \\
\hline & $<0.62$ n (\%) & $\geq 0.62$ n (\%) & \\
\hline \multicolumn{4}{|c|}{ Local Failure } \\
\hline Yes & $12(38.7)$ & $4(23.5)$ & 0.04 \\
\hline No & 19 (61.3) & $13(76.5)$ & \\
\hline \multicolumn{4}{|c|}{ Regional Failure } \\
\hline Yes & $9(29.0)$ & $2(11.8)$ & 0.02 \\
\hline No & $22(71.0)$ & $15(88.2)$ & \\
\hline \multicolumn{4}{|c|}{ Distant Failure } \\
\hline Yes & $14(45.2)$ & $2(11.8)$ & 0.02 \\
\hline No & $17(54.9)$ & $15(88.2)$ & \\
\hline \multicolumn{4}{|c|}{ Last Situation } \\
\hline Alive & $16(51.6)$ & $13(76.5)$ & 0.04 \\
\hline Exitus & $15(48.4)$ & $4(23.5)$ & \\
\hline
\end{tabular}

\section{Metabolic Response}

The median pretreatment SUVmax was 11.37 (range: 3.30-26.00). All patients had at least one PET/CT scan in follow-up. At the first PET-CT scan after SBRT according to EORTC criteria for metabolic response, 8 (16.7\%) patients achieved complete responses, 35 (72.9\%) patients achieved partial response, $3(6.3 \%)$ patients had stable disease, and $2(4.2 \%)$ patients had progressive disease. The median posttreatment SUVmax was 4.30 (range: 1.0-14.30).

\section{Findings on the $\Delta$ SUVmax Values Between Pre- post SBRT PET/CT Scans}

As a result of ROC curve analysis, cutoff $\triangle \mathrm{SUV}$ max was calculated 0.62 with maximum sensitivity and specificity (sensitivity $79 \%$, specificity $45 \%$ ). Median $\triangle$ SUVmax was 0.56 maximum $\triangle$ SUVmax was 0.94 in favor of regression, and maximum $\triangle$ SUVmax was 0.34 in favor of progression. Metabolic complete or partial response assessed by the EORTC criteria was $90 \%$ at $12-16$, weeks. In 7 of 8 patients with complete response after SBRT $\triangle$ SUVmax was $>0.62$ and in 2 patients with progression $\Delta$ SUVmax was $\leq 0.62$. 


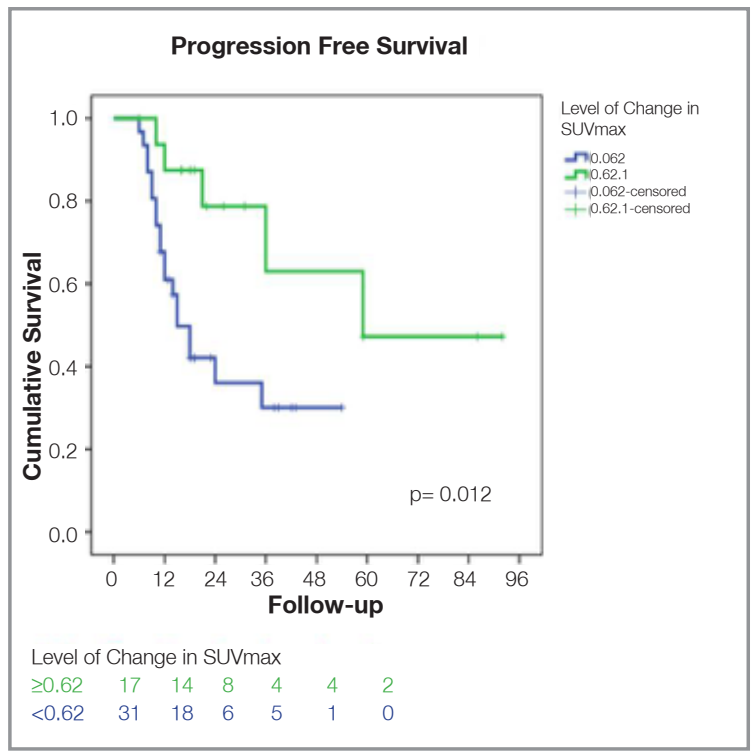

Figure 1. Progression free survival stratified by $\Delta S U V \max$ below and above 0.62

\section{Clinical Outcomes}

Median follow-up was 23 (range: 6-92) months and in this period local, regional and distant relapse were developed after SBRT in 16 (33.3\%), $11(22.9 \%)$, and $16(33.3 \%)$ patients, respectively. Twenty nine $(60.4 \%)$ patients were alive at the time of analysis (Table 3 ).

In patients with $\triangle$ SUVmax $<0.62$, median PFS was 15 (range: 6-54) months and 1-, 3- year PFS rates were $61 \%, 30 \%$, respectively. In patients with $\Delta$ SUVmax $\geq 0.62$, median PFS was 59 (range: 10 92) months and 1-, 3- year PFS rates were $87 \%$, $63 \%$, respectively $(\mathrm{p}=0.012)$ (Figure 1$)$. In pa-

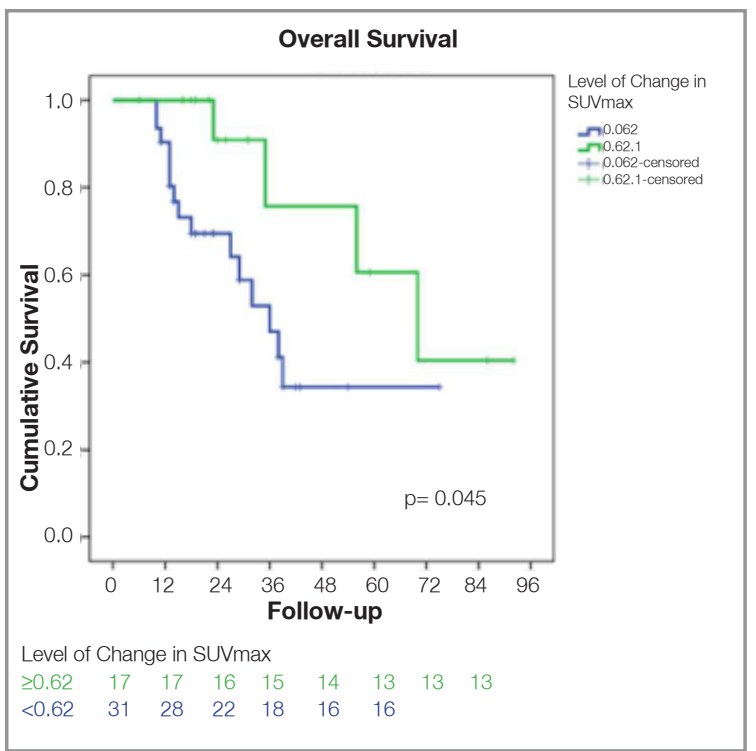

Figure 2. Overall survival stratified by $\Delta S U V m a x$ below and above 0.62

tients with $\triangle$ SUVmax $<0.62$, median OS was 36 (range: 10-75) months and OS rates for 1, 3 and 5 year were $90.3 \%, 47 \%$ and $34 \%$, respectively. In patients with $\triangle$ SUVmax $\geq 0.62$, median OS was 70 (range: 23-92) months and OS rates for 1, 3 and 5 year were $90.9 \%, 75 \%$ and $60 \%$, respectively ( $\mathrm{p}=$ 0.045) (Figure 2). In univariate analysis, sex, age, KPS, tumor histology, T stage, PTV volume, and BED10 was not significantly associated with and both PFS, and OS. In both univariate and multivariate analysis, the lower $\triangle$ SUVmax level (as both dichotomous and continuous variable) was determined as a negative prognostic factor on PFS. In

Table 4. Univariate and multivariate Cox proportional hazards regression analysis

\begin{tabular}{|c|c|c|c|c|}
\hline & \multicolumn{4}{|c|}{ Univariate Cox proportional hazards regression analysis } \\
\hline & \multicolumn{2}{|c|}{$\Delta S U V \max (<0.62$ vs $\geq 0.62)$} & \multicolumn{2}{|c|}{$\Delta$ SUVmax (Continuous) } \\
\hline & HR (95\% Cl) & $\mathbf{p}$ & HR (95\% Cl) & $\mathbf{p}$ \\
\hline Progression free survival & $3.6(1.22-10.6)$ & 0.02 & $6.89(1,95-24.31)$ & 0.003 \\
\hline \multirow[t]{2}{*}{ Overall survival } & $3.1(0.98-9.83)$ & 0.55 & $3.04(0.74-13.13)$ & 0.14 \\
\hline & \multicolumn{4}{|c|}{ Multivariate Cox proportional hazards regression analysis } \\
\hline Progression free survival & $4.06(1.35-12.23)$ & 0.013 & $6.86(1,96-23.87)$ & 0.003 \\
\hline Overall survival & $3.1(0.98-9.82)$ & 0.05 & $2.26(0.49-10.45)$ & 0.3 \\
\hline
\end{tabular}


addition to this, in multivariate analysis it has been showed that the lower $\Delta$ SUVmax level (only as a dichotomous variable) is a negative prognostic factor on OS (Table 4).

\section{DISCUSSION}

Inflammatory reactions after radiotherapy may cause false positive assessments in PET/CT images in the first 6-12 weeks and for this reason it is recommended to perform the PET/CT at the earliest 2-3 months after radiotherapy. The value of PET/CT for predicting treatment outcomes and prognosis in esNSCLC patients treated with SBRT has been investigated in several studies. In these studies SUVmax is the most frequently tested vigorous and reproducible parameter. However SUV is adjusted according to body weight and it is not independent of body mass and size. As body mass index and body weight increase, the level of SUV in the blood and normal tissues also increases. So, ideal body weight, lean body mass or body surface area values are used instead of body mass in SUV calculation. ${ }^{18}$ Because of SUVmax only gives information for a point of voxel (volumetric pixel) within the tumor and does not fully reflect tumor size and heterogeneity, some of studies showed pretreatment SUVmax to be a prognostic factor, while some did not do so. ${ }^{10,19-21}$ It has been reported that SUVmax was a predictor for survival and intensive treatment regimens may improve outcomes in patients with high SUVmax. ${ }^{10}$ Nair et al., and others reported conflicting results regarding the idea that various cut off levels of SUVmax on PET/CT were associated with poor results in patients with esNSCLC managed with radiation alone. ${ }^{19,22-24}$ For this reason, it has been followed by studies involving volume based parameters (VBP) such as metabolic tumor volume (MTV) and total glycolysis (TLG). ${ }^{25}$ Contradictory results on this subject have been reported in a few studies. For example, Vu et al. could not show any correlation between SUVmax, but Satoh et al. showed that SUVmax, MTV and TLG were significantly associated with DFS. ${ }^{26,27}$ Although there are some advantages of VBP in measuring the metabolic response, there is still controversy about the most appropriate method to measure MTV and TLG. ${ }^{28}$ In addition, it was reported that treatment response and PFS, OS could be evaluated by TLG as early earliest at as the $2 \mathrm{nd}$ week after the beginning of treatment in patients with locally advanced NSCLC. ${ }^{29,30}$

In a meta-analysis of 9 studies involving 1166 patients with stage I NSCLC who were treated with curative surgery, the median overall survival in the high FDG uptake group was 70\% (range: $17-87 \%$ ) compared with $88 \%$ (range: $74-100 \%$ ) in the low FDG uptake groups. ${ }^{31}$ In another meta-analysis, it has been revealed that the SUVmax value of the primary tumor was positively correlated with the prognosis in heterogeneous NSCLC patient groups. ${ }^{32}$ Dong et al., demonstrated correlations between pre-treatment SUVmax with the OS, local control and distant metastases. But this analysis identified significant heterogeneity in the methods of studies such as SBRT dose and fractionations, scanner of PET, cut-off level for SUV value and softwware. ${ }^{33}$ Changes in FDG uptake during and after SBRT has been observed by Wiegman et al. and they reported that PET/CT during SBRT could not predict the outcomes of treatment. ${ }^{34}$ Henderson et al. also did not support using of routine PET/CT imaging for follow-up after SBRT in patients with stage I NSCLC. ${ }^{15}$ However, post-treatment tumor FDG uptake has been demonstrated as an important prognostic factor in locally advanced NSCLC patients treated with concurrent chemoradiotherapy in a large prospective trial. ${ }^{35} \mathrm{~A}$ significant correlation between post-SBRT tumor SUVmax and distant failure in patients with medically inoperable esNSCLC has been showed in only one study in the literature. In this study, it has been reported that 2 and higher value of post-SBRT SUVmax and lower than 2.55 reduction SUVmax after SBRT is associated with a higher risk of distant failure. ${ }^{36} \mathrm{At}$ the same time, Bollineni et al. reported that FDG uptake on PET/CT at 12 weeks after SBRT could predict local control for stage I NSCLC. ${ }^{17}$

Due to the inadequacy of SUVmax use alone and the difficulties in measuring and evaluating the volumetric parameters, in present study, we investigated the prognostic significance of $\triangle \mathrm{SUVmax}$ which is an easily calculated and evaluated parameter. As a result of our analysis we can suggest that the PFS and OS are better in esNSCLC patients with $\triangle$ SUVmax higher than 0.62 after SBRT. In the literature, there are various studies involving 
NSCLC patients at with in different stages. As mentioned above, Clarke et al., showed that reduction of $<2.55$ in SUVmax after SBRT is associated with a higher risk of distant failure. However, this negative effect has not been reflected in survival. ${ }^{36}$ Pöttgen et al., in their study involving 50 patients with locally advanced NSCLC, assessed treatment response as regularly by PET/CT in patients treated with 3 cycles of induction chemotherapy followed by chemoradiotherapy. After the treatment response evaluation, 37 patients were accepted as resectable and the surgery was performed, it was reported that 45-62\% declines in SUVmax on PET/ CT after completion of treatment correlated with histopathologic response. ${ }^{37}$ Cerfolio et al. in their study involving 56 patients showed that $80 \%$ or more reduction and complete response in SUVmax after neoadjuvant chemotherapy is associated with complete response independently of cell type. ${ }^{38}$ Similarly, Vansteenkiste et al. showed that 50\% reduction in SUVmax after induction chemotherapy was associated with better survival in studies involving patients with locally advanced NSCLC. ${ }^{39}$

\section{CONCLUSION}

Although, there are some limitations of this study including short follow-up time, small sample size and retrospective design, we demonstrated that $\triangle$ SUVmax is a prognostic factor in esNSCLC patients who were treated with SBRT and patients with $\triangle$ SUVmax higher than 0.62 have better PFS and OS.

\section{REFERENCES}

1. Kavanagh BD, Timmerman RD. Stereotactic radiosurgery and stereotactic body radiation therapy: an overview of technical considerations and clinical applications. Hematol Oncol Clin North Am 20: 87-95, 2006.

2. Chi A, Liao Z, Nguyen NP, et al. Systemic review of the patterns of failure following stereotactic body radiation therapy in early-stage non-smallcell lung cancer: clinical implications. Radiother Oncol 94: 1-11, 2010.

3. Timmerman R, Paulus R, Galvin J, et al. Stereotactic body radiation therapy for inoperable early stage lung cancer. JAMA 303: 1070-1076, 2010.
4. Grutters JP, Kessels AG, Pijls-Johannesma M, et al. Comparison of the effectiveness of radiotherapy with photons, protons and carbon-ions for non-small cell lung cancer: a meta-analysis. Radiother Oncol 95: 32-40, 2010

5. Verstegen NE, Oosterhuis JW, Palma DA, et al. Stage I-II non-small-cell lung cancer treated using either stereotactic ablative radiotherapy (SABR) or lobectomy by video-assisted thoracoscopic surgery (VATS): outcomes of a propensity score-matched analysis. Ann Oncol 24: 1543-1548, 2013.

6. Chang JY, Senan S, Paul MA, et al. Stereotactic ablative radiotherapy versus lobectomy for operable stage I non-smallcell lung cancer: a pooled analysis of two randomised trials. Lancet Oncol 16: 630-637, 2015.

7. Hicks RJ. Role of 18 F-FDG PET in assessment of response in non-small cell lung cancer. J Nucl Med 50: 31-42, 2009.

8. Mac Manus MP, Hicks RJ, Matthews JP, et al. Positron emission tomography is superior to computed tomography scanning for response-assessment after radical radiotherapy or chemoradiotherapy in patients with non-small-cell lung cancer. J Clin Oncol 21: 1285-1292, 2003.

9. Eschmann SM, Friedel G, Paulsen F, et al. 18F-FDG PET for assessment of therapy response and preoperative reevaluation after neoadjuvant radio-chemotherapy in stage III nonsmall cell lung cancer. Eur J Nucl Med Mol Imaging 34: 463471, 2007.

10. Takeda A, Sanuki N, Fujii $H$, et al. Maximum standardized uptake value on FDG-PET is a strong predictor of overall and disease-free survival for nonsmall-cell lung cancer patients after stereotactic body radiotherapy. J Thorac Oncol 9: 65-73, 2014.

11. Dahele M, Palma D, Lagerwaard F, et al. Radiological changes after stereotactic radiotherapy for stage I lung cancer. J Thorac Oncol 6: 1221-1228, 2011.

12. Dunlap NE, Yang W, Mclntosh A, et al. Computed tomography-based anatomic assessment overestimates local tumor recurrence in patients with mass-like consolidation after stereotactic body radiotherapy for early-stage non-small cell lung cancer. Int J Radiat Oncol Biol Phys 84: 1071-1077, 2012.

13. Ursino S, Fiorica F, Colosimo C, Micucci M, Stefanelli A, Berretta $\mathrm{M}$, et al. Metabolic responses in non-small cell lung cancer after hypofractionated stereotactic radiotherapy PET and hypofractionated radiotherapy. Eur Rev Med Pharmacol Sci 16: 755-762, 2012.

14. Takeda A, Kunieda E, Fujii H, et al. Evaluation for local failure by 18 F-FDG PET/CT in comparison with CT findings after stereotactic body radiotherapy (SBRT) for localized nonsmall-cell lung cancer. Lung Cancer 79: 248-253, 2013.

15. Henderson MA, Hoopes DJ, Fletcher JW, et al. A pilot trial of serial $18 \mathrm{~F}$-fluorodeoxyglucose positron emission tomography in patients with medically inoperable stage I non-smallcell lung cancer treated with hypofractionated stereotactic 
body radiotherapy. Int J Radiat Oncol Biol Phys 76: 789-795, 2010.

16. Essler M, Wantke J, Mayer B, et al. Positron emission tomography $\mathrm{CT}$ to identify local recurrence in stage I lung cancer patients 1 year after stereotactic body radiation therapy. Strahlenther Onkol 189: 495-501, 2013.

17. Bollineni VR, Widder J, Pruim J, et al. Residual ${ }^{18} \mathrm{~F}-\mathrm{FDG}$-PET uptake 12 weeks after stereotactic ablative radiotherapy for stage I non-small-cell lung cancer predicts local control. Int J Radiat Oncol Biol Phys 83: e551-555, 2012.

18. Sugawara $Y$, Zasadny KR, Neuhoff AW, Wahl RL. Reevaluation of the standardized uptake value for FDG: variations with body weight and methods for correction. Radiology 213: 521-525, 1999.

19. Hamamoto $Y$, Sugawara $Y$, Inoue $T$, et al. Relationship between pretreatment FDG uptake and local control after stereotactic body radiotherapy in stage I non-small-cell lung cancer: the preliminary results. Jpn J Clin Oncol 41: 543-547, 2011.

20. Hoopes DJ, Tann M, Fletcher JW, et al. FDG-PET and stereotactic body radiotherapy (SBRT) for stage I non-small-cell lung cancer. Lung Cancer 56: 229-234, 2007.

21. Burdick MJ, Stephans KL, Reddy CA, et al. Maximum standardized uptake value from staging FDG-PET/CT does not predict treatment outcome for early-stage non-small-cell lung cancer treated with stereotactic body radiotherapy. Int J Radiat Oncol Biol Phys 78: 1033-1039, 2010.

22. Nair VJ, MacRae R, Sirisegaram A, Pantarotto JR. Pretreatment [18F]-fluoro-2-deoxy-glucose positron emission tomography maximum standardized uptake value as predictor of distant metastasis in early-stage non-small cell lung cancer treated with definitive radiation therapy: rethinking the role of positron emission tomography in personalizing treatment based on risk status. Int J Radiat Oncol Biol Phys 88: 312318, 2014.

23. Horne ZD, Clump DA, Vargo JA, et al. Pretreatment SUVmax predicts progression-free survival in early-stage non-small cell lung cancer treated with stereotactic body radiation therapy. Radiat Oncol 9: 41, 2014.

24. Shirai K, Abe T, Saitoh Jl, et al. Maximum standardized uptake value on FDG-PET predicts survival in stage I non-small cell lung cancer following carbon ion radiotherapy. Oncol Lett 13: 4420-4426, 2017

25. Takahashi N, Yamamoto T, Matsushita H, et al. Metabolic tumor volume on FDG-PET/CT is a possible prognostic factor for Stage I lung cancer patients treated with stereotactic body radiation therapy: a retrospective clinical study. J Radiat Res 57: 655-661, 2016.

26. Dibble EH, Alvarez AC, Truong MT, et al. 18F-FDG metabolic tumor volume and total glycolytic activity of oral cavity and oropharyngeal squamous cell cancer: adding value to clinical staging. J Nucl Med 53: 709-715, 2012.
27. Shirata $Y$, Jingu K, Koto M, et al. Prognostic factors for local control of stage I non-small cell lung cancer in stereotactic radiotherapy: a retrospective analysis. Radiat Oncol 7: 182, 2012.

28. Ypsilantis PP, Siddique M, Sohn HM, et al. Predicting response to neoadjuvant chemotherapy with PET imaging using convolutional neural networks. PLoS One 10: e0137036, 2015.

29. Usmanij EA, de Geus-Oei LF, Troost EG, et al. 18F-FDG PET early response evaluation of locally advanced non-small cell lung cancer treated with concomitant chemoradiotherapy. J Nucl Med 54: 1528-1534, 2013.

30. Yossi S, Krhili S, Muratet JP, et al. Early assessment of metabolic response by 18F-FDG PET during concomitant radiochemotherapy of non-small cell lung carcinoma is associated with survival: a retrospective single-center study. Clin Nucl Med 40: 215-221, 2015.

31. Nair VS, Krupitskaya Y, Gould MK. Positron emission tomography 18F-fluorodeoxyglucose uptake and prognosis in patients with surgically treated, stage I non-small cell lung cancer: a systematic review. J Thorac Oncol 4: 1473-1479, 2009.

32. Na F, Wang J, Li C, et al. Primary tumor standardized uptake value measured on F18-Fluorodeoxyglucose positron emission tomography is of prediction value for survival and local control in non-small-cell lung cancer receiving radiotherapy: meta-analysis. J Thorac Oncol 9: 834-842, 2014.

33. Dong M, Liu J, Sun X, Xing L. Prognositc significance of SUVmax on pretreatment 18 F-FDG PET/CT in early-stage non-small cell lung cancer treated with stereotactic body radiotherapy: A meta-analysis. J Med Imaging Radiat Oncol 61: 652-659, 2017.

34. Wiegman EM, Pruim J, Ubbels JF, et al. 18F-FDG PET during stereotactic body radiotherapy for stage I lung tumours cannot predict outcome: a pilot study. Eur J Nucl Med Mol Imaging 38: 1059-1063, 2011.

35. Machtay M, Duan F, Siegel BA, et al. Prediction of survival by [18F] fluorodeoxyglucose positron emission tomography in patients with locally advanced nonsmall-cell lung cancer undergoing definitive chemoradiation therapy: results of the ACRIN 6668/ RTOG 0235 trial. J Clin Oncol 31: 3823-3830, 2013.

36. Clarke K, Taremi M, Dahele M, et al Stereotactic body radiotherapy (SBRT) for non-small cell lung cancer (NSCLC): is FDG-PET a predictor of outcome? Radiother Oncol 104: 62-66, 2012.

37. Pöttgen C, Levegrün S, Theegarten D, et al. Value of $18 \mathrm{~F}$ fluoro-2-deoxy-D-glucose-positron emission tomography/ computed tomography in non-small-cell lung cancer for prediction of pathologic response and times to relapse after neoadjuvant chemoradiotherapy. Clin Cancer Res 12: 97-106, 2006. 
38. Cerfolio RJ, Bryant AS, Winokur TS, et al. Repeat FDGPET after neoadjuvant therapy is a predictor of pathologic response in patients with non-small cell lung cancer. Ann Thorac Surg 78: 1903-1909, 2004.

39. Vansteenkiste JF, Stroobants SG, De Leyn PR, et al. Potential use of FDG-PET scan after induction chemotherapy in surgically staged IIla-N2 non-small-cell lung cancer: a prospective pilot study. The Leuven Lung Cancer Group. Ann Oncol 9: 1193-1198, 1998.

\section{Correspondence:}

\section{Dr. Gokhan YAPRAK}

Saglik Bilimleri Universitesi

Kartal Dr. Lutfi Kirdar Egitim ve Arastirma Hastanesi

Radyasyon Onkolojisi Anabilim Dali

Kartal

ISTANBUL / TURKEY

Tel: (+90-533) 6645789

e-mail: gokhanyaprak@gmail.com 